UDC 629.735.017.1.083 (045),

DOI: $10.18372 / 1990-5548.52 .11887$

${ }^{1}$ Y. V. Hryshchenko,

${ }^{2}$ V. G. Romanenko,

${ }^{3}$ Y. Y. Hryshchenko

\title{
SUGGESTIONS OF THE IMPROVEMENT OF THE QUALITY OF FLIGHT DURING LANDING AND MISSED APPROACH/ GO AROUND MANEUVER
}

\author{
${ }^{1,2}$ Educational \& Research Institute of Air Navigation, National Aviation University, Kyiv, Ukraine \\ ${ }^{3}$ Department of intelligent control, International Research and Training Centre for Information Technologies \\ and Systems of NAS of Ukraine and MES of Ukraine \\ E-mails: ${ }^{1}$ hryshchenko8y@ gmail.com, ${ }^{2}$ noktinua rvg11235@ukr.net, ${ }^{3}$ noktinua@gmail.com
}

\begin{abstract}
In this article, the questions of the approaching the glide path of airplane in the horizontal plane are considered, suggestions are given on the analysis of the correlation fields and the alarm system in case dangerous flight regimes of flight. Antistress training methods are proposed. Requirement of alarm at go-around maneur is substantiated in case of flight during conditions. A system of warning of a steering wheel rapid movements on go-around was developed.
\end{abstract}

Index Terms-Glide path; correlation function; dynamic stereotype; negative factors.

\section{INTRODUCTION}

Civil Aviation is one of the leading field of the national economy, equipped with the modern aviation technology. The main indicators of the civil aviation activity are passenger turnover, flight safety, flight regularity, and economic efficiency. Every year, according to ICAO, the number of the flight events caused by the "human factor" increases.

Extremely large impact on the human-operator are made by the complex flight conditions. In this case, the quality of piloting technology is deteriorating and false actions occur.

\section{PRoblem Statement}

At present, the most problematic phases of the flight are landing and missed approach/ GO AROUND maneuver. Previously, the authors considered issues of approaching the glide path in the vertical plane and recommendations for training operators while they were affected by the negative factors in these phases of the flight.

In this article, the questions of the approaching the glide path in the horizontal plane and the proposals for signaling while performing missed approach/ GO AROUND maneuver are considered. The requirements of engineering psychology is also taken into account.

A way to improve the method of analyzing the contours of correlation fields is proposed. The necessity of signaling at the exit of a missed approach/ GO AROUND maneuver under special conditions of flight, which can improve safety and quality of flights is shown.

The purpose is to develop methods for assessing the airplane's ergonomic control system in extreme flight conditions and warning systems for deteriorating flight quality.
Methods of research - analysis of the correlation functions, analysis of the experimental data of the field experiment.

\section{TRAJECTORY OF THE APPROACHING THE GLIDE PATH IN THE HORIZONTAL PLANE}

The deviation of the flight path from the target heading is characterized by the correlation function between the given and the realized flight paths. In this paper, the physical meaning of the correlation function is analyzed. The connection between the correlation function and the difference between the planned and actual flight paths is determined.

Let's consider the flight trajectory of the aircraft at a constant altitude, so we get plane $z=$ const. The coordinate y represents the lateral deviation from the flight path line. Horizontally, at a certain fixed area, it has an initial reference point $x_{1}$ and a final reference point $x_{2}$ (Fig. 1).

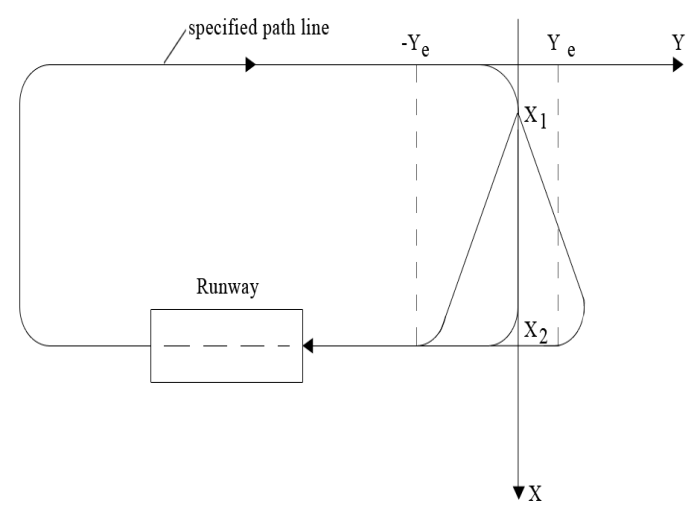

Fig. 1. Scheme of entering the glide path in the horizontal plane

The square of the integral difference of the planned and real flight trajectories in a certain section is equal to: 


$$
\Delta=\int_{x_{1}}^{x_{2}}\left[Y_{3}(x)-Y_{p}(x)\right]^{2} d x
$$

where $Y_{3}(x)$ is the planned flight trajectory; $Y_{p}(x)$ is the implemented flight trajectory; $x_{1}, x_{2}$ are starting and ending points of the horizontal flight trajectories.

Let's make the algebraic transformation of the expression (1)

$$
\Delta=\int_{x_{1}}^{x_{2}} Y_{3}^{2}(x) d x-2 \int_{x_{1}}^{x_{2}} Y_{3}(x) Y_{p}(x) d x+\int_{x_{1}}^{x_{2}} Y_{p}^{2}(x) d x .
$$

Denote the components of equation (2)

$$
\begin{aligned}
& \int_{x_{1}}^{x_{2}} Y_{3}^{2}(x) d x=L \rho_{3}, \\
& \int_{x_{1}}^{x_{2}} Y_{3}(x) Y_{p}(x) d x=L \rho_{3 p}, \\
& \int_{x_{1}}^{x_{2}} Y_{p}^{2}(x) d x=L \rho_{p},
\end{aligned}
$$

where $L=x_{2}-x_{1}$, functions $\rho_{3}, \rho_{3 p}, \rho_{p}$ is the autocorrelation functions of the planned flight accordingly, $\left(\rho_{3}\right)$ correlation function between the planned trajectory and the real trajectory $\left(\rho_{3 p}\right)$ and $\rho_{p}$ is the autocorrelation function of the real flight path.

Now represent expression (2) in the form:

$$
\Delta=L \rho_{3}-2 L \rho_{3 p}+L \rho_{p^{\prime}}
$$

Since the autocorrelation functions $\rho_{3}$ and $\rho_{p}$ are approximately equal to each other, then we take

$$
\rho_{3} \approx \rho_{p} \approx \rho_{A}
$$

$\rho_{A}$ is the function of autocorrelation of the planned and realized process.

We rewrite formula (3) with accordance to (4)

$$
\Delta=2 L\left(\rho_{A}-\rho_{3 p}\right), \quad \rho_{3 p}=\rho_{A}-\frac{\Delta}{2 L} .
$$

It is clear from (5) that if the trajectories coincide $\Delta=0$, then $\rho_{3 p}=\rho_{A}$.

The value of the integral error per unit length $\frac{\Delta}{2 L}$ is equal to the difference between the autocorrelation functions $\rho_{A}$ and the correlation $\rho_{3 p}$. We calculate these three functions for different types of trajectories.

Now consider the flight trajectory, which is defined by the expression:

$$
Z_{3}(x)=y-\frac{y}{L} x
$$

where $y$ is the initial lateral deviation from the trajectory; $L$ is the flight length in a given area.

Let's consider the particular case - the delay of the aircraft approaching the intended flight path

$$
Z_{p}=y-\frac{y}{L}(x-\chi)
$$

where $\chi$ is the delay value.

Then the correlation and autocorrelation functions are equal:

$$
\begin{gathered}
\rho_{3}=\frac{1}{L} \int_{L}^{0}\left(y-\frac{y}{L} x\right) d x=\frac{y^{2}}{3}, \\
\rho_{p 3}=\frac{1}{L} \int_{L}^{0}\left(y-\frac{y}{L} x\right)\left[y-\frac{y}{L}(x-\chi)\right] d x \\
=\frac{y^{2}}{3}+\frac{y^{2}}{2 L} \chi-\frac{y^{2}}{2 L^{2}} \chi^{2}+\frac{y^{3}}{6 L^{2}} \chi^{3}, \\
\rho_{k}=\frac{1}{L} \int_{L}^{0}\left[y-\frac{y}{L}(x-\chi)\right] d x=\frac{y^{2}}{3}+\frac{y^{2}}{2 L} \chi \\
+\frac{1}{2} \frac{y^{2}}{2 L^{2}} \chi^{2}+\frac{y^{3}}{6 L^{2}} \chi^{3} .
\end{gathered}
$$

In what follows we denote $\rho(-\chi)$.

We substitute the values ( $8 \mathrm{a}, \mathrm{b}$ and $\mathrm{c})$ in the formula (3) and find the integral difference between two trajectories

$$
\begin{aligned}
\Delta=L & \frac{y^{3}}{3}-2 L \frac{y^{2}}{3}-2 L \frac{y^{2}}{2 L} \chi+2 L \frac{y^{2}}{2 L^{2}} \chi^{2}-2 L \frac{y^{2}}{6 L^{3}} \chi^{3} \\
+ & L \frac{y^{2}}{3}+L \frac{y^{2}}{L} \chi+2 L \frac{y^{2}}{2 L^{2}} \chi^{2}+L \frac{y^{2}}{6 L^{3}} \chi^{3}=\frac{2}{3} L y^{2} \\
& -\frac{2}{3} L y^{2}+\frac{3 y^{2}}{L} \chi^{2}-\frac{y^{2}}{6 L^{2}} \chi^{3}=\frac{3 y^{2}}{L} \chi^{2}-\frac{y^{2}}{6 L^{2}} \chi^{3}
\end{aligned}
$$

when $\chi=0, \Delta=0, \chi=L, \Delta=\frac{17}{18} L y^{2}$.

Let's write (7) as:

$$
\Delta=3 L y^{2}\left(\frac{\chi}{L}\right)^{2}-\frac{1}{6} L y^{2}\left(\frac{\chi}{L}\right)^{3} .
$$

From equation (8) it is clear that with increasing $\chi$ from 0 to $L$ the value increases.

The flight path during the lead mode is equal:

$$
Z(x+\chi)=y-\frac{y}{L}(x+\chi) .
$$

We split the range $(0, L)$ into two sections $(0, L-\chi)$ and $(0, L+\chi)$. The lead function on the 
section $(L-\chi, L)$ is equal to zero $Z(x+\chi)=0$. Thus, the lead correlation function is determined by integration only in the gap $(0, L-\chi)$

$$
\begin{array}{r}
\rho_{3 p}=\rho(+\chi)=\frac{1}{L} \int_{0}^{L-\chi}\left(y-\frac{y}{L} x\right)\left[y-\frac{y}{L}(x+\chi)\right] d x \\
=\frac{y^{2}}{3}-\frac{y^{2}}{2 L} \chi+\frac{y^{2}}{6 L^{3}} \chi^{3} .
\end{array}
$$

Equating the expressions (8b) and (12)

$$
\rho(-\chi)-\rho(+\chi)=\frac{y^{2}}{L} \chi-\frac{y^{2}}{2 L^{2}} \chi^{2},
$$

we can conclude:

$$
\rho(-\chi)>\rho(\chi) .
$$

The autocorrelation function of the lead path is:

$$
\begin{gathered}
\rho_{k}(+\chi)=\frac{1}{L} \int_{0}^{L}\left[y-\frac{y}{L}(x+\chi)\right]^{2} d x \\
=\frac{y^{2}}{L} \int_{0}^{L}\left[1-\frac{x+\chi}{L}\right]^{2} d x \\
=\left(\frac{y^{2}}{L}-\frac{2 y^{2}}{L^{2}} \chi+\frac{y^{2}}{L^{3}} \chi^{2}\right)(L-\chi) \\
\quad-\frac{y^{2}}{L^{2}}(L-\chi)^{2}+\frac{y^{2}}{3 L^{3}}(L-\chi)^{3} .
\end{gathered}
$$

The conditions of an unreal flight can be represented by the expression $\rho(-\chi)-\rho(+\chi)=0$, when $\chi=2 L$.

Under the condition $L \gg \chi$, the delay value is much smaller than the path length, which is quite realistic, the autocorrelation function of the lead path is

$$
\rho_{k}(+\chi)=\frac{1}{3} y^{2}-\frac{2 y^{2}}{L} \chi+\frac{y^{2}}{L^{2}} \chi^{2} .
$$

Now substitute in the equation (3) the values $\rho_{3}, \rho_{k}(+\chi)$ and $\rho_{3 k}(+\chi)$, we get:

$$
\begin{aligned}
\frac{\Delta}{L}=\frac{1}{3} y^{2}-\frac{2}{3} y^{2}+ & \frac{y^{2}}{L} \chi-\frac{y^{2}}{3 L^{3}} \chi^{3}+\frac{1}{3} y^{2}-\frac{2 y^{2}}{L} \chi \\
+ & \frac{y^{2}}{L^{2}} \chi^{2}+\frac{1}{3} y^{2}-\frac{2 y^{2}}{L} \chi+\frac{y^{2}}{L^{2}} \chi^{2} \\
& =\frac{1}{3} y^{2}-\frac{3 y^{2}}{L} \chi+\frac{2 y^{2}}{L^{2}} \chi^{2}-\frac{y^{2}}{3 L^{3}} \chi^{3} .
\end{aligned}
$$

Thus, the ratio of the square of the integral difference of the trajectories to the length of the trajectory has a quadratic dependence on the lateral deviation.

\section{ANTISTRESS TRAINING OF AVIATION PERSONNEL}

The methods developed earlier [1] allow to teach pilots how to counter the factor loads, but their further implementation was stopped due to the lack of financing.

Previously, crashes of Boeing 737 type aircraft were considered in case of performing missed approach/ GO AROUND maneuver in the difficult weather conditions [2]. It should be noted that with a high probability pilots of these aircraft would not have made a disproportionate and sharp actions with steering wheel in the case of training through the above methods.

Interesting proposals are presented in an article on the analysis of correlation fields [3], [4,]. The correlation between $\alpha$ (angle of attack) and $\gamma$ (bank angle) is analyzed there.

With complex failures associated with the transition from the flight sections of the trajectory to the uncompleted sections and back, the effects of complete transformation and transformation of planar contour figures into linear configurations can be seen.

In the case of failures that are not related to the transition to the nonflight sections of the trajectory, effects of compression and reduction of the areas of contour figures (contours) of the correlation fields are observed. A transition to the analysis of the contours of correlation fields is proposed for the recognition of a contour figure, which is limited to detecting the signs of complex failures by 4-6 reference points while revealing the fact of the change in the field area.

It should be also noted that the existing sliding pointer or the computing system with the accelerometer partially performs this function. It is clear that an uncoordinated turn, exceeding the angle of attack $\alpha$ with poor roll coordination, can only increase the time to stall in the spin with loss of speed.

Therefore, it is necessary to analyze a threedimensional coordinate system. From what has been said above, it follows that false readings of instrument speed represent the greatest danger.

The main aims of anti-stress training are: decreasing of risks, coincides with operators' "opposition to superposition factors (SF)" training; establishing ergonomically optimal flight control systems.

In accordance with factor model of action and counter-action in flight (MACF) and taking into 
account nature of intensified reflexes (IR), flights are considered as extremely complex processes contain risks caused by expected processes, uncertainties and occasions, external errors. The most complex flight uncertainties are SF. SF is an interaction between factors. There was no scientific works before, which consider training of IR saving under SF action. Our model allows to take into account this training.

One more distinctive feature of our model is that more earlier prevention of accident is a variant of aftereffect. Also MACF allows to prevent accident thanks to SIR (even during negative flight or at presence additional error).

Difficulty of solving this problem is considering very much of interacted factors. Our scientists distinguish more than 1500 of these factors. So, problem of aircrew error prevention is very difficult (even when causes sure known) [1].

The possibility of determining of counteraction of a pilot from negative superposition factors on

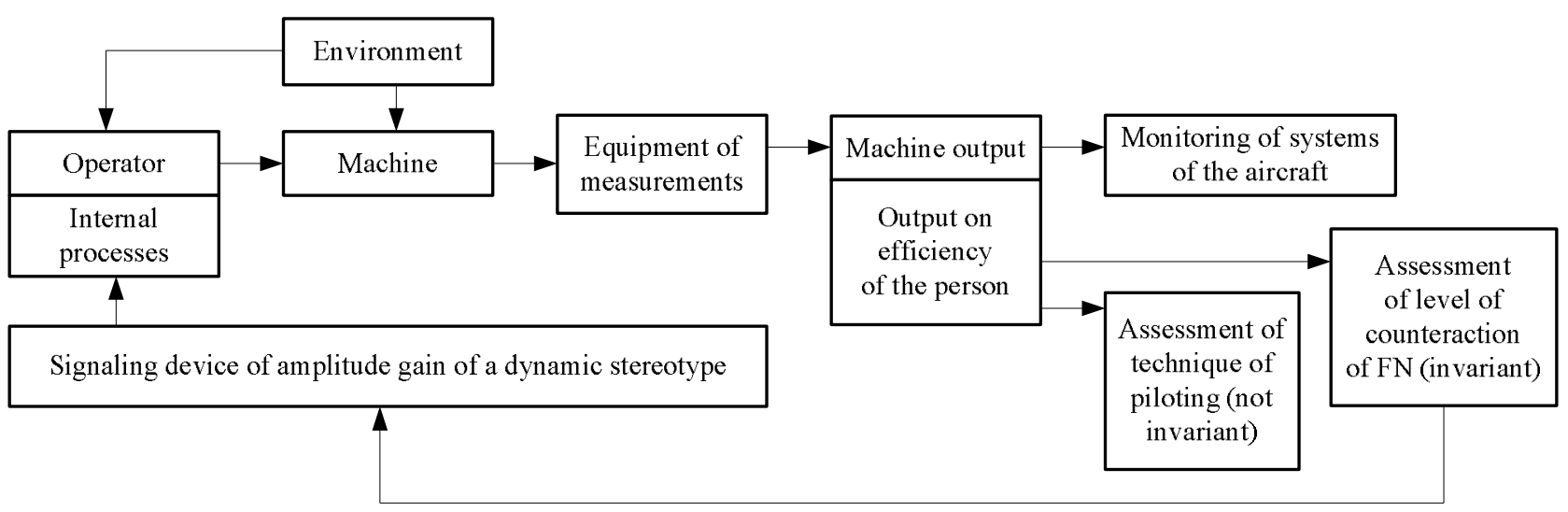

Fig. 2. Method of pilot's characteristics determination through machine approach

It was found that the pilot's handwriting, when exposed to FN, does not change and it can only be fixed by changing of the amplitude of the flight parameters [2].

\section{THE WARNING SySTEM THE SHARP WHEEL MOVEMENTS AT THE APPROACHING THE SECOND CIRCLE}

As a result of the analysis of the events presented in the article [2], we can conclude that it is necessary to develop and install the system of warning of the avoidance of sharp up-down movements on Boeing737 aircraft when it approahes the second loop in a steady state during the difficult weather conditions and during excavation the plane from dumping.

The Language informant system GPWS (Ground proximity warning system) generates the "PULL UP" signal in 20-30 seconds before a calculated collision with a relief or an artificial obstacle. When modern aircraft flight parameters, evaluating the effectiveness is shown on Fig. 2.

In the course investigation was established that the invariance of the "man-machine" allows determining the invariant properties and characteristics of the human operator for the engine output without placing a contact and contactless psychophysiological sensors which basically carry the information about characteristics of the humanoperator that is mathematically described by the general theory of oscillations. The oscillatory nature of the output characteristics of the human operator allows to make a conclusion for tracking systems, that the engine outputs systems are invariant with respect to the input characteristics of the system, if the input of such a system works by a human operator. From the general theory of automatization and automatic control systems is well known, that in relation to all types of oscillations (sinusoidal, modulated, with a random spectrum, etc.), existing systems are invariant under the scheme "inputprocess-output" [1]. the alarm "PULL UP" is activated, the crew deactivates the autopilot and throttle, removes the interceptors if they are released, manually outputs engines to the maximum operating mode and immediately transfers the plane to the set height.

If necessary, the pitch can be increased up to the alarm signaling about the approaching speed of dumping. In this case, it is important to avoid sharp movements with a steering wheel from itself to prevent nosedown [5].

Alarm is triggered when the conditions are met:

$$
\sqrt{\Delta \alpha_{i}^{2}+V_{y i}^{2}+\theta_{i}^{2}}>\sqrt{\Delta \alpha_{\text {inst }}^{2}+V_{y \text { inst }}^{2}+\theta_{i \text { inst }}^{2}},
$$

where $\Delta \alpha_{i}$ and $\Delta \alpha_{\text {inst }}$ is the current and the maximum magnitude of the angle of attack respectively; $V_{y i}$ and $V_{y \text { inst }}$ is the current and the maximum permissible values of the vertical speed of 
the aircraft; $\theta_{i}^{2}$ and $\theta_{i \text { inst }}^{2}$ is the current and installed magnitude of the pitch angle.

$$
V_{\text {instr }}<V_{\text {inst }}+\Delta V
$$

where $V_{\text {instr }}$ is the indicated airspeed of the aircraft; $V_{\text {inst }}$ is the sufficient/established speed of aircraft at which stalling starts; $\Delta V$ is the increase in speed required to trigger a warning signal of sharp movements.

The angle of attack is calculated as follows:

$$
\Delta \alpha=\frac{\alpha_{\max }+\alpha_{\min }}{\alpha_{\min }}, \quad \alpha_{\min } \neq 0,
$$

where $\Delta \alpha$ is the magnitude of the angle of attack; $\alpha_{\max }$ is the critical value of the angle of attack, at which the flow stops; $\alpha_{\min }$ is the minimum value of the angle of attack amplitude.

The functional scheme of the development device - the warning alarm of the prevention of the sharp movements presented on the Fig. 3.

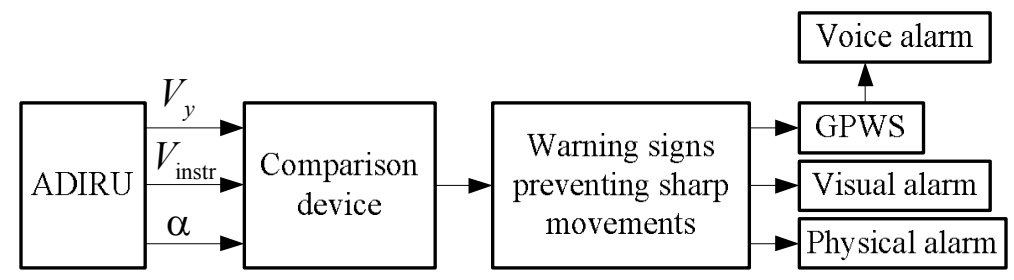

Fig. 3. The functional scheme of the warning alarm of the prevention of the sharp movements

There are three types of alarm: voice (the command "SLIGHTLY", smoothly), visual (illuminated text display on the steering wheel) and physical (small increase of the pilot's efforts for the movement of the steering wheel).

Alarms are triggered simultaneously.

The command "SLIGHTLY" is used in pairs with GPWS, because the signaling of this system reports about the possible convergence with the ground. The sound signal "SLIGHTLY" goes after the "PULL UP" signal while missed approach.

The visual alarm lights up the "PULL UP SLIGHTLY" text indicator in yellow, this color is used to indicate boundary modes that require caution. The visual indication in the case of off-line alert in the form of gray text without its illumination on a steering wheel of a Boeing 737 NG type is shown in Fig. 4.

Working out of visual warning about preventing the sharp movements is shown on Fig. 5.

Physical alarm assumes an artificial reduction in the wheel's sensitivity by $25 \%$, which increases the pilot's effort to move the steering wheel along the longitudinal axis to prevent sharp movements with the steering wheel, which can lead to dive.

\section{CONCLUSION}

Delay in the approaching the glide path in the horizontal plane is more dangerous than lead mode.

In analyzing the contours of correlation fields at the angles of the roll and the attack, it is necessary to take into account the indicated speed of the aircraft. For this purpose, it is necessary to carry out calculations of mistakes of the first and second kinds.

In order to improve the training of a humanoperator for actions in special situations of flight with failures of avionics it is proposed to increase the number of complex failures in "flights" on complex simulators of the aircraft.

The necessity of the alarm is shown at missed approach under the special conditions of flight, which can improve safety and quality of flights.

The developed system of warning of sharp movements of the wheel on missed approach is aimed to improve the safety of flights. Two accidents that occurred for this reason could have been avoided if there was a signaling device on Boeing 737.

\section{REFERENCES}

[1] Y. V. Hryshchenko. "Scientific research on the antistress preparation of specialists in a quarter century," Proceedingss of the National Aviation University, 2014, no. 1, pp. 53-58.

[2] Y. V. Hryshchenko, V. G. Romanenko, V. D. Tronko, and Y. Y. Hryshchenko. "Methods of training of modern aircraft flight crews for inflight abnormal circumstances," Proceedings of the National Aviation University, 2017, no. 1, pp. 66-72.

[3] E. M. Hohlov, Y. V. Hryshchenko, and O. N. Volodko. "Method for determining the quality of piloting along the contours of the correlation fields of flight parameters in special conditions," Cybernetics and Computer Science. Scientific journal, 2016, no. 183 , pp. 39-51.

[4] Y. V. Hryshchenko. "Reliability problem of ergatic control systems in aviation." Methods and Systems of Navigation and Motion Control. IEEE 4th International Conference (October 18-20, 2016), Kyiv, Ukraine, pp. 126-129.

[5] Y. V. Hryshchenko. "Methods for assessing the quality of an airplane system in extreme flight conditions," Diploma work of the graduate of the "Master" educational-qualification level. National Aviation University, Kyiv, 2017, 91 p.

Received January 28, 2017 


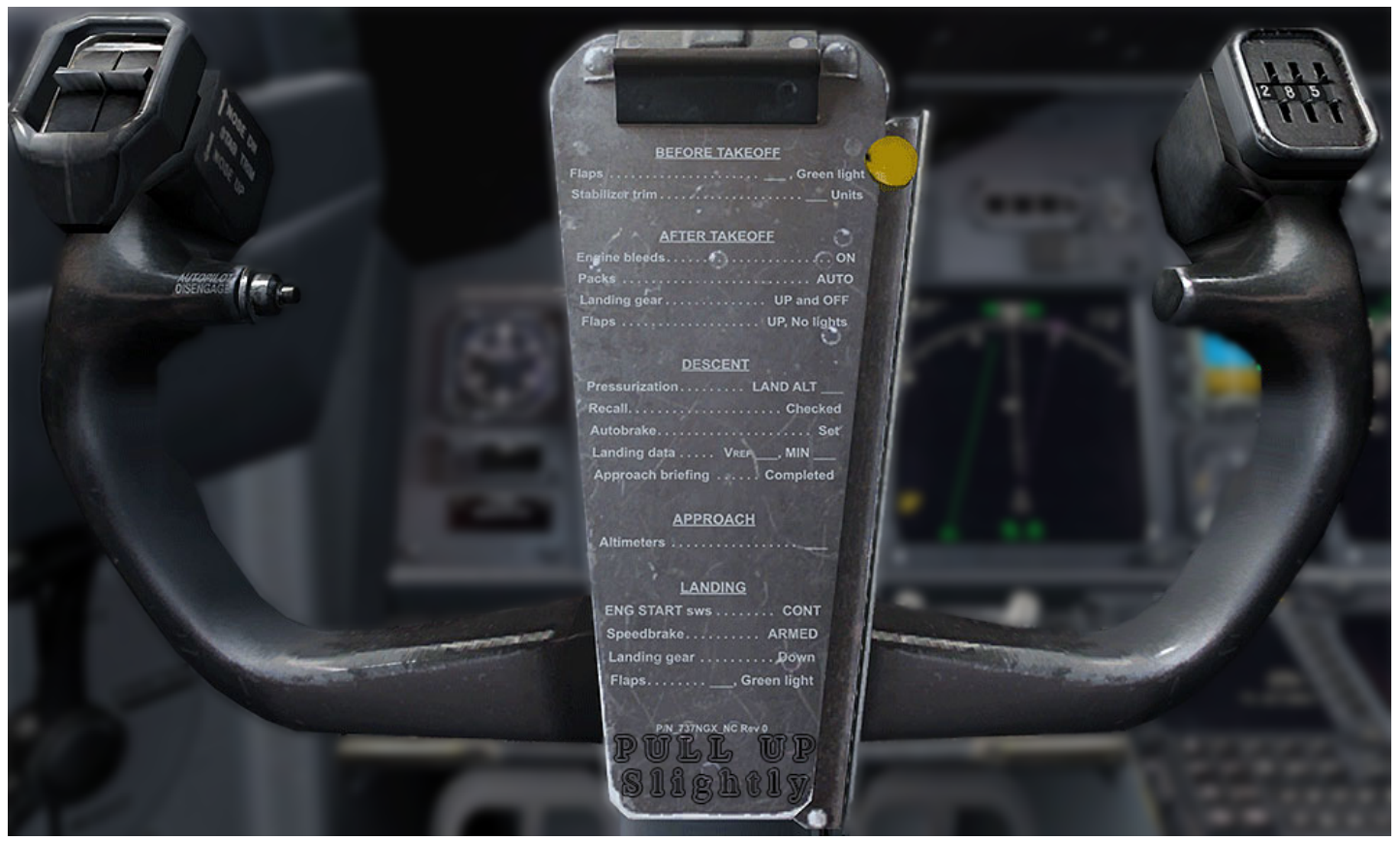

Fig. 4. Indication of the warning signal for preventing sharp movements on the steering wheel when the alarm is off

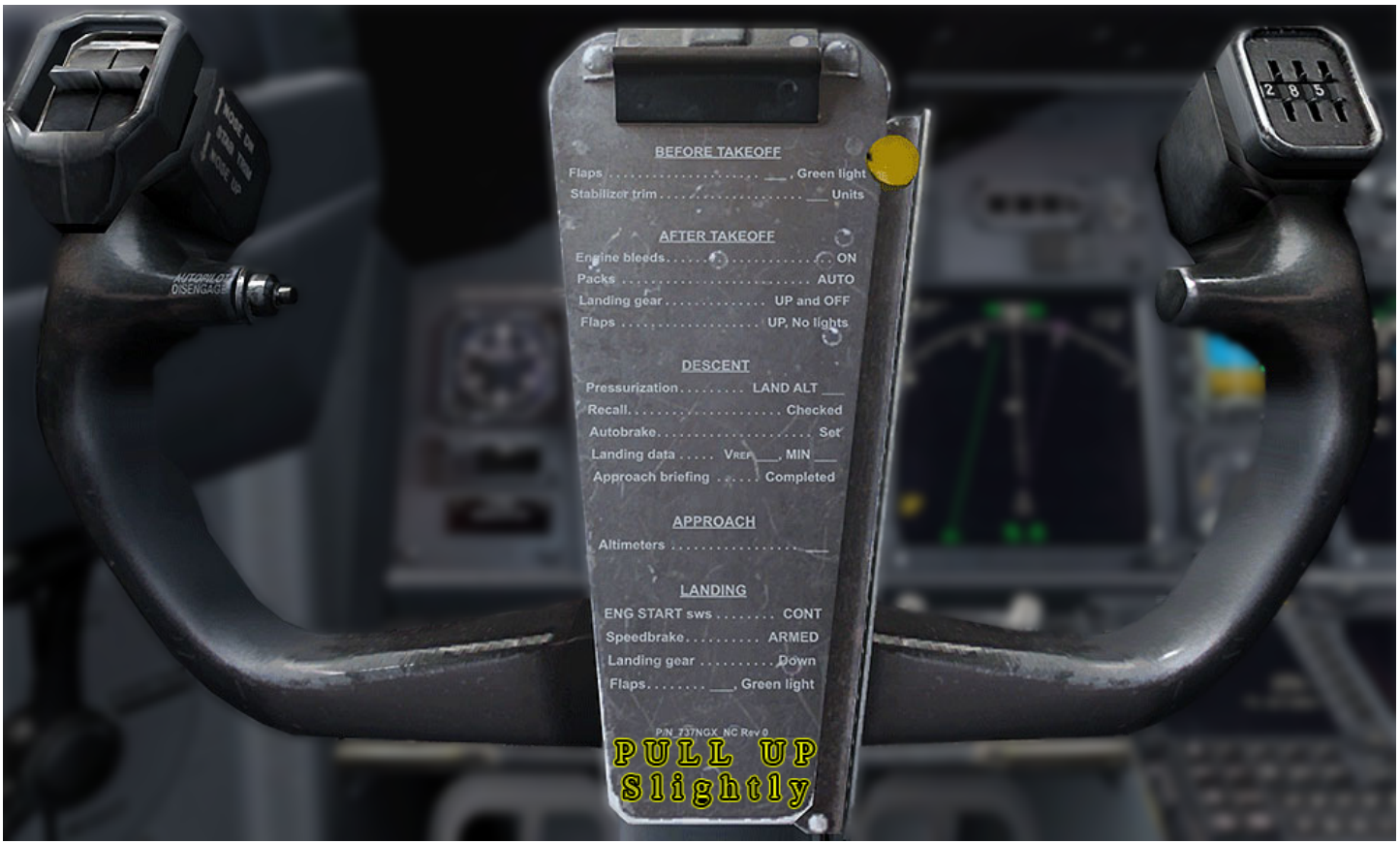

Fig. 5. Indication of the alarm trigger warning of preventing sharp movements on the steering wheel

Hryshchenko Yurii. Candidate of Science (Engineering). Associate Professor.

Avionics Department, Education \& Research Institute of Air Navigation, National Aviation University, Kyiv, Ukraine. Education: Kyiv Civil Aviation Engineers Institute, Kyiv, Ukraine (1987).

Research interests: flight safety and dependability of technical and ergonomics systems.

Publications: 41.

E-mail: hryshchenko8y@gmail.com

Romanenko Viktor. Candidate of Science (Engineering). Associate Professor.

Avionics Department, Education \& Research Institute of Air Navigation, National Aviation University, Kyiv, Ukraine. Education: Kyiv Civil Aviation Engineers Institute, Kyiv, Ukraine (1988).

Research interests: cavitation in liquid systems and optoelectronics.

Publications: 61.

E-mail: rvg11235@ukr.net 
Hryshchenko Yurii. Master. Senior engineer.

Department of intelligent control, International Research and Training Center for Information Technologies and Systems of NAS of Ukraine and MES of Ukraine.

Education: National Aviation University, Kyiv, Ukraine (2017).

Research interests: flight safety and dependability of technical and ergonomics systems.

Publications: 1.

E-mail: noktinua@gmail.com

Ю. В. Грищенко, В. Г. Романенко, Ю. Ю. Грищенко. Пропозиції щодо підвищення якості польоту при посадці і відході на друге коло

Розглянуто питання входу в глісаду літака у горизонтальній площині, надано пропозиції щодо аналізу кореляційних полів і системи сигналізації про небезпечні режими польоту. Запропоновано методи антистресової підготовки. Обгрунтовано необхідність введення сигналізації у разі виходу літака на друге коло при виникненні особливих випадків польоту. Розроблено систему попередження різких рухів штурвалом при виході літака на друге коло.

Ключові слова: глісада; функція кореляції; динамічний стереотип; негативні чинники.

Грищенко Юрій Віталійович. Кандидат технічних наук. Доцент.

Кафедра авіоніки, Навчально-науковий інститут аеронавігації, Національний авіаційний університет, Київ, Україна. Освіта: Київський інститут інженерів цивільної авіації, Київ, Україна (1987).

Напрям наукової діяльності: безпека польотів і надійність технічних і ергатичних систем.

Кількість публікацій: 41.

E-mail: hryshchenko8y@gmail.com

Романенко Віктор Григорович. Кандидат технічних наук. Доцент.

Кафедра авіоніки, Навчально-науковий інститут аеронавігації, Національний авіаційний університет, Київ, Україна. Освіта: Київський інститут інженерів цивільної авіації, Київ, Україна (1988).

Кількість публікацій: 61.

E-mail: rvg11235@ukr.net

Грищенко Юрій Юрійович. Магістр. Провідний інженер.

Міжнародний науково-навчальний центр інформаційних технологій та систем НАН України та МОН України.

Освіта: Національний авіаційний університет, Київ, Україна (2017).

Наукові інтереси: безпека польотів і надійність технічних і ергатичних систем.

Кількість публікацій: 1.

E-mail: noktinua@gmail.com

Ю. В. Грищенко, В. Г. Романенко, Ю. Ю. Грищенко. Предложения по повышению качества полета при посадке и уходе на второй круг

Рассмотрены вопросы входа в глиссаду в горизонтальной плоскости, даны предложения по анализу корреляционных полей и системе сигнализации про опасные режимы полета. Предложены методы антистрессовой подготовки. Обоснована необходимость введения сигнализации при уходе самолета на второй круг при возникновении особых случаев полета. Разработана система предупреждения резких движений штурвалом при уходе самолета на второй круг.

Ключевые слова: глиссада; функция корреляции; динамический стереотип; негативные факторы.

Грищенко Юрий Витальевич. Кандидат технических наук. Доцент.

Кафедра авионики, Национальный авиационный университет, Учебно-научный институт аэронавигации, Киев, Украина.

Образование: Киевский институт инженеров гражданской авиации, Киев, Украина (1987).

Направление научной деятельности: безопасность полетов и надежность технических и эргатических систем.

Количество публикаций: 41.

E-mail: hryshchenko8y@gmail.com

Романенко Виктор Григорьевич. Кандидат технических наук. Доцент.

Кафедра авионики, Национальный авиационный университет, Учебно-научный институт аэронавигации, Киев, Украина.

Образование: Киевский институт инженеров гражданской авиации, Киев, Украина (1988).

Количество публикаций: 61.

E-mail:rvg11235@ukr.net

Грищенко Юрий Юрьевич. Магистр. Ведущий инженер.

Международный научно-учебный центр информационных технологий и систем НАН Украины и МОН Украины.

Образование: Национальный авиационный университет, Киев, Украина (2017).

Научные интересы: безопасность полетов и надежность технических и эргатических систем.

Количество публикаций: 1.

E-mail: noktinua@gmail.com 